\title{
STRATEGI PEMUPUKAN TANAMAN KARET DALAM MENGHADAPI HARGA KARET YANG RENDAH
}

\author{
Rubber Plant Fertilization Strategies in Dealing of Low Rubber Prices \\ Jamin Saputra \\ Balai Penelitian Sembawa, Pusat Penelitian Karet \\ Jalan Palembang - Pangkalan Balai, Km. 29 Po. Box. 1127 Palembang 30001 \\ Email : jamincomsu@yahoo.com
}

Diterima 6 September 2018 / Direvisi 6 Desember 2018 / Disetujui 20 Desember 2018

\begin{abstract}
Abstrak
Pemeliharaan tanaman karet melalui pemupukan merupakan salah satu langkah penting yang harus dilakukan untuk mencapai pertumbuhan dan produksi yang optimal. Akhir-akhir ini ketersediaan pupuk yang terbatas, harga yang terus meningkat, dan harga karet yang rendah menyebabkan kegiatan pemupukan pada perkebunan karet sering tertunda. Selain penundaan kegiatan pemupukan juga terjadi pengurangan dosis dan bahkan meniadakan kegiatan pemupukan. Tulisan ini bertujuan untuk mengkaji hasil-hasil penelitian dalam upaya peningkatan efisiensi pemupukan pada tanaman karet sehingga biaya pemupukan dapat dikurangi. Hasil-hasil penelitian sebelumnya menunjukkan bahwa pemupukan dapat dikurangi sampai $75 \%$ dari dosis pupuk tunggal apabila menerapkan teknologi pemupukan menggunakan pupuk majemuk dengan tambahan slow release agent yang sering disebut dengan Slow Release Fertilizer(SRF) dan upaya lain dengan menggunakan kombinasi pupuk tunggal dengan pupuk hayati. Selain itu penentuan dosis rekomendasi harus mempertimbangkan sifat tanah sehubungan dengan kapasitas tanah dalam menyediakan unsur hara untuk tanaman, faktor lingkungan yang mempengaruhi efisiensi pemupukan, serta kebutuhan tanaman akan unsur hara sesuai dengan umur, produksi, dan kesehatan tanaman. Pada kondisi pekebun yang mengalami kesulitan melakukan pemupukan
\end{abstract}

akibat harga karet yang rendah maka penundaan pemupukan selama dua tahun belum memberikan efek kerugian finansial bagi pekebun.

Katakunci: pemupukan, tanaman karet, harga karet rendah.

\section{Abstract}

Maintenance of rubber plant through fertilization is one of the important steps that must be done to achieve optimal growth and production. Lately, the limited of fertilizer availability, prices continue to rise, and low rubber prices cause fertilization activities on the rubber plantation are often delayed. Besides delaying fertilization on activities, there was also reduce the dose of fertilizer and even negate fertilization activities. Therefore, this paper aims to review the results of previous research in an effort to increase the efficiency of fertilization on the rubber so the costs of fertilization can be reduced. The results of the previous research showed that fertilization can be reduced up to $75 \%$ of single fertilizer dose when applying the fertilizing technology used an additional compound fertilizer with the slow release agent which is often called a Slow Release Fertilizers (SRF) or a combination of single fertilizers with biological fertilizer. In addition, dosage recommendations should consider the nature of the land in relation to the capacity of the soil to provide nutrient for the plants, the environmental factors that affect the efficiency of fertilization, as well as the needs of the plant nutrient elements in accordance with the age, production, and 
health of plants. On the conditions there the planters of the difficulties do fertilization because of the low rubber price the fertilization delay for two years will not give the effect to financial losses.

Key words: fertilization, rubber plant, low rubber prices.

\section{Pendahuluan}

Tanah idealnya dapat menyediakan sejumlah unsur hara penting yang dibutuhkan oleh tanaman. Hara yang terserap tanaman seharusnya dapat segera diperbaharui sehingga kandungan unsur hara di dalam tanah tetap seimbang. Hutan adalah contoh ekosistem yang seimbang. Pengambilan unsur hara oleh ribuan jenis tumbuhan diimbangi dengan pelapukan bahan organik yang mensuplai hara bagi tanah. Proses inilah yang menyebabkan tanah di bawah ekosistem hutan tetap subur (Istianto, 2010).

Dalam siklus unsur hara, tanah merupakan tempat cadangan utama unsur hara. Secara umum telah diketahui bahwa sebagian besar hara hilang dari dalam tanah pada perkebunan karet melalui pengambilan oleh tanaman, immobilisasi pada tanaman karet, penutup tanah, dan vegetasi lain yang tumbuh di areal tersebut. Selain itu, sebagian unsur hara juga hilang melalui pencucian, volatilisasi, denitrifikasi, produksi lateks, serta bagian tanaman yang diangkut keluar areal dan erosi.
Pada saat yang bersamaan hara di dalam tanah diperkaya oleh penambahan bagian-bagian tanaman karet yang mati, penutup tanah, fiksasi nitrogen oleh kacangan, pemupukan maupun penambahan hara yang terlarut dalam air hujan, serta debu yang terkumpul (Istianto, 2006).

Pemeliharaan tanaman karet melalui pemupukan merupakan salah satu langkah vital yang harus dilakukan untuk mencapai produktivitas optimal. Akhir-akhir ini ketersediaan pupuk yang terbatas dan harga yang terus meningkat menyebabkan kegiatan pemupukan sering tertunda. Harga pupuk yang terus meningkat dapat disebabkan oleh beberapa faktor seperti peningkatan permintaan pupuk dan biaya transportasi (Sembiring et al., 2013). Selain kendala faktor eksternal tersebut, faktor internal dari pengusaha perkebunan karet juga mengharuskan peningkatan efisiensi karena harga karet yang rendah sehingga terjadi penurunan daya beli. Akibat rendahnya harga karet mulai tahun 2014-2018 terutama tahun 2016 (Singapore/Malaysia Rubber Price, 2018) menyebabkan banyak perusahaan perkebunan karet yang mengurangi dosis pemupukan dari dosis anjuran dan bahkan ada yang meniadakan kegiatan pemupukan. Oleh karena itu perlu adanya kajian dari hasil-hasil penelitian sebelumnya dalam upaya peningkatan efisiensi pemupukan pada tanaman karet.

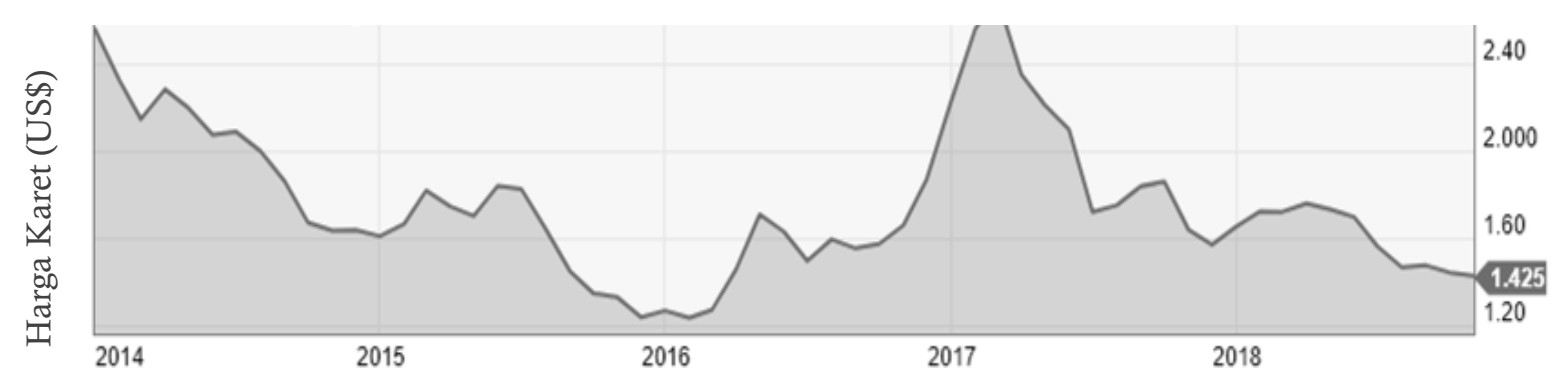

Sumber: Singapore/Malaysia Rubber Price, (2018)

Gambar 1. Grafik fluktuasi harga karet tahun 2014-2018 
Pada artikel ini disajikan beberapa teknologi hasil penelitian tentang pemupukan yang dapat diterapkan pada perkebunan karet untuk meningkatkan efisiensi pemupukan. Adapun teknik pemupukan yang akan dibahas antara lain pemupukan sesuai dengan kebutuhan tanaman, penggunaan pupuk majemuk, dan penggunaan pupuk hayati.

\section{A. Pemupukan Sesuai dengan Kebutuhan Tanaman}

Tanaman karet agar tumbuh dan berproduksi dengan baik memerlukan kecukupan hara. Pemupukan tanaman karet menghasilkan (TM) dapat meningkatkan produksi sampai $15-30 \%$ dan dapat mempersingkat masa tanaman belum menghasilkan (TBM) menjadi 4-5 tahun (Adiwiganda et al., 1994). Menurut Adiwiganda et al. (1994), kegiatan pemupukan harus dirancang dengan seksama dan terarah agar dapat dicapai efisiensi pemupukan. Artinya dengan biaya pemupukan yang rendah dapat memberikan hasil yang optimal. Dalam rangka pencapaian efisiensi pemupukan, maka dalam penyusunan dosis rekomendasi pemupukan harus mempertimbangkan kandungan hara tanah sehubungan dengan kapasitas tanah untuk menyediakan unsur hara bagi tanaman, faktor lingkungan seperti kondisi gulma yang mempengaruhi efisiensi pemupukan, serta kebutuhan tanaman akan unsur hara sesuai dengan umur, produksi, dan kesehatan tanaman. Oleh karena itu, perlu dilakukan analisis tanah dan daun tanaman pada luasan tertentu yang sering disebut LSU (Leaf Sampling Unit).

Blok tanaman yang akan dijadikan LSU harus memiliki kesamaan jenis tanah, klon, umur tanaman, dan tindakan kultur teknis. Luas LSU berkisar antara 16-48 ha dengan pengambilan contoh tanah dan daun tersebar sebanyak 20-30 tempat. Menurut Sihotang \& Istianto (1994) pengambilan contoh daun dilakukan setiap tahun dan contoh tanah cukup dilakukan lima tahun sekali. Pengambilan contoh daun dilakukan pada saat daun telah mencapai perkembangan fisiologi yang maksimum, karena pada stadia ini fisiologi dan mekanisme hara dalam daun telah mencapai keadaan stabil. Keadaan tersebut dicapai pada saat daun berumur 90120 hari, pada tanaman menghasilkan (TM) dihitung sejak musim gugur daun berakhir dan dua bulan setelah pemupukan terakhir selesai. Pengambilan contoh tanah dilakukan di sekitar areal pemupukan yang berjarak $150 \mathrm{~cm}$ dari pohon contoh, tanah diambil pada kedalaman 0-20 cm.

Penyusunan rekomendasi pemupukan tanaman karet dilakukan berdasarkan fungsi sebagai berikut(Adiwiganda et al., 1994):

$$
\begin{aligned}
& \text { DR }=\text { DU }-(a \times \text { IHT }+b \times \text { IHD }+c x \text { ISPT }+d x \\
& \text { IGA) } x \text { e } x \text { DU + HT }
\end{aligned}
$$

Keterangan :

$$
\begin{aligned}
\mathrm{DR} & =\begin{array}{l}
\text { dosis rekomendasi } \\
\text { (gram/pohon/tahun) }
\end{array} \\
\mathrm{DU} & =\begin{array}{l}
\text { dosis umum hasil percobaan } \\
\text { (gram/pohon/tahun) }
\end{array} \\
\mathrm{IHT} & =\text { indeks hara tanah } \\
\mathrm{IHD} & =\text { indeks hara daun } \\
\mathrm{ISPT} & =\text { indeks serangan penyakit } \\
\mathrm{IGA} & =\text { indeks gangguan angin } \\
\mathrm{HT} & =\text { hara terkuras karena peningkatan } \\
& \text { produksi } \\
\text { a-e } & =\text { konstanta }
\end{aligned}
$$

Indeks hara tanah dan daun ditetapkan berdasarkan hasil analisis laboratorium. Analisis di laboratorium untuk mengetahui kadar hara daun meliputi $\mathrm{N}, \mathrm{P}, \mathrm{K}, \mathrm{Ca}$ dan $\mathrm{Mg}$ dan hara tanah meliputi C-organik, $\mathrm{N}, \mathrm{P}_{2} \mathrm{O}_{5}$, $\mathrm{K}_{2} \mathrm{O}$ dan $\mathrm{MgO}$, serta analisis sifat kimia tanah yaitu $\mathrm{pH} \mathrm{H}_{2} \mathrm{O}$ tanah dan Kapasitas Tukar Kation (KTK). Kandungan hara daun dan tanah kemudian diberi indeks berdasarkan klasifikasi hara tanaman dan tanah yang disusun oleh Adiwiganda et al. (1994). Indeks 0 menunjukkan kecukupan hara, sedangkan indeks positif dan negatif masing-masing menunjukkan status hara yang tinggi dan rendah. Koreksi dosis pupuk dilakukan untuk kelebihan produksi (HT) di atas standar produksi dengan sistem sadap konvensional. Koreksi dosis juga dilakukan apabila terjadi 
serangan penyakit yang menyebabkan gugur daun. Thomas et al. (2003) melaporkan bahwa tanaman karet yang memiliki kandungan hara kalium tinggi memiliki ketahanan lebih baik terhadap serangan penyakit gugur daun Corrynespora.

\section{B. Pemupukan Menggunakan Pupuk Majemuk}

Pemupukan di perkebunan karet umumnya menggunakan pupuk tunggal. Sementara efisiensi pemupukan menggunakan pupuk tunggal masih rendah, hal ini dikarenakan pupuk tunggal seperti Urea, dan $\mathrm{KCl}$ rentan terhadap pencucian (leaching) dan penguapan (volatilisasi). Noeriwan \& Noeriza (2004), melaporkan efisiensi pemupukan $\mathrm{N}$ umumnya di bawah $50 \%$ walaupun dengan pengelolaan yang baik. Sedangkan Achmad \& Susetyo (2014), melaporkan bahwa kehilangan unsur hara $\mathrm{N}$ sebesar $21,5 \%$ akibat pupuk diaplikasikan setelah 15 jam dari pencampuran pupuk. Upaya yang dilakukan untuk meningkatkan efisiensi pemupukan yaitu dengan menggunakan pupuk majemuk dengan tambahan slow release agent yang sering disebut dengan Slow Release Fertilizer(SRF).

Salah satu jenis pupuk majemuk SRF yang pernah diuji pada perkebunan karet adalah pupuk NPK tablet. Wijaya et al. (2014) melaporkan bahwa secara umum perlakuan pemupukan dengan pupuk NPK tablet menunjukkan kandungan hara di daun lebih tinggi dibandingkan dengan kontrol dan dosis anjuran pupuk tunggal (Tabel 1). Kandungan hara $\mathrm{P}, \mathrm{K}, \mathrm{Ca}$, dan $\mathrm{Mg}$ tidak berbeda nyata antar perlakuan. Namun hara $\mathrm{N}$ berbeda nyata antar perlakuan. Pemuukan dengan menggunakan NPK tablet kandungan hara N lebih tinggi dibandingkan dengan pupuk tunggal karena adanya tambahan slow release agent pada pupuk NPK tablet tersebut. Perlakuan yang tidak berbeda nyata tersebut disebabkan karena adanya pengaruh sisa dari pemupukan pada tahun-tahun sebelumnya.

Pengaruh pemupukan menggunakan NPK tablet terhadap pertambahan tebal kulit pulihan disajikan pada Tabel 2. Tebal kulit pulihan pada akhir penelitian menunjukkan terjadi perbedaan yang nyata antar perlakuan dimana perlakuan tanpa pemupukan menunjukkan tebal kulit pulihan yang paling rendah. Perlakuan pupuk majemuk NPK tablet setara $75 \%$ dosis umum pupuk tunggal merupakan perlakuan dengan tebal kulit pulihan yang paling tinggi diantara perlakuan lainnya. Perlakuan pupuk majemuk NPK tablet setara $15 \%, 20 \%$, dan $50 \%$ dosis umum tidak berbeda nyata dengan perlakuan dosis umum pupuk tunggal (Wijaya et al., 2014).

Hasil pengamatan produksi disajikan pada Tabel 3. Produksi tanaman karet selama satu tahun pertama penyadapan belum menunjukkan perbedaan yang nyata pada semua perlakuan. Hal ini dikarenakan pengaruh sisa dari pemupukan tahun sebelumnya. Namun pengaruh pemupukan tersebut pada tahun kedua terhadap produksi rata-rata telah menunjukkan perbedaan yang

Tabel 1. Kandungan hara daun (\%) pada beberapa perlakuan diakhir penelitian

\begin{tabular}{llllll}
\hline \multicolumn{1}{c}{ Perlakuan } & N (\%) & P (\%) & K (\%) & Ca (\%) & Mg (\%) \\
\hline Kontrol (tanpa pemupukan) & $2,35^{\mathrm{a}}$ & $0,31^{\text {tn }}$ & $1,06^{\text {th }}$ & $0,53^{\text {tn }}$ & $0,23^{\text {tn }}$ \\
Dosis umum pupuk tunggal & $2,56^{\text {ab }}$ & 0,31 & 0,96 & 0,51 & 0,27 \\
$750 \mathrm{~g} / \mathrm{ph} /$ th NPK tablet (setara 75\% pupuk tunggal) & $3,96^{\mathrm{c}}$ & 0,38 & 1,05 & 0,97 & 0,29 \\
$500 \mathrm{~g} / \mathrm{ph} /$ th NPK tablet (setara 50\% pupuk tunggal) & $3,95^{\mathrm{c}}$ & 0,35 & 0,97 & 0,91 & 0,23 \\
$250 \mathrm{~g} / \mathrm{ph} /$ th NPK tablet (setara 25\% pupuk tunggal) & $3,99^{\mathrm{c}}$ & 0,35 & 1,06 & 0,92 & 0,31 \\
$150 \mathrm{~g} / \mathrm{ph} /$ th NPK tablet (setara 15\% pupuk tunggal) & $3,97^{\mathrm{c}}$ & 0,31 & 0,86 & 1,01 & 0,29 \\
\hline
\end{tabular}

Keterangan : angka yang diikuti huruf yang sama menunjukkan tidak berbeda nyata pada tingkat signifikasi $95 \%,{ }^{\text {tn }}$ : tidak nyata.

Sumber: Wijaya etal. (2014) 
Tabel 2. Data tebal kulit pulihan (mm) pada beberapa perlakuan setelah dua tahun aplikasi

\begin{tabular}{lc}
\hline \multicolumn{1}{c}{ Perlakuan } & Tebal Kulit Pulihan (mm) \\
\hline Kontrol (tanpa pemupukan) & $4,3^{\mathrm{a}}$ \\
Dosis umum pupuk tunggal & $4,9^{\mathrm{ab}}$ \\
$750 \mathrm{~g} / \mathrm{ph} /$ th NPK tablet (setara 75\% pupuk tunggal) & $5,5^{\mathrm{b}}$ \\
$500 \mathrm{~g} / \mathrm{ph} / \mathrm{th}$ NPK tablet (setara 50\% pupuk tunggal) & $5,3^{\mathrm{ab}}$ \\
$250 \mathrm{~g} / \mathrm{ph} /$ th NPK tablet (setara 25\% pupuk tunggal) & $5,2^{\mathrm{ab}}$ \\
$150 \mathrm{~g} / \mathrm{ph} /$ th NPK tablet (setara 15\% pupuk tunggal) & $5,1^{\mathrm{ab}}$ \\
\hline
\end{tabular}

Keterangan : angka yang diikuti huruf yang sama menunjukkan tidak berbeda nyata pada tingkat signifikasi $95 \%$.

Sumber:Wijaya et al. (2014)

Tabel 3. Pengaruh beberapa perlakuan pemupukan terhadap produksi tanaman karet (gram/pohon/sadap)

\begin{tabular}{lcc}
\hline \multirow{2}{*}{ Perlakuan } & \multicolumn{2}{c}{$\begin{array}{c}\text { Rata-Rata Produksi } \\
\text { (gram/pohon/sadap) }\end{array}$} \\
\cline { 2 - 3 } & Tahun ke 1 & Tahun ke 2 \\
\hline Kontrol (tanpa pemupukan) & $39,90^{\mathrm{tn}}$ & $36,58^{\mathrm{a}}$ \\
Dosis umum pupuk tunggal & 38,80 & $38,08^{\mathrm{ab}}$ \\
$750 \mathrm{~g} / \mathrm{ph} /$ th NPK tablet (setara 75\% pupuk tunggal) & 39,81 & $40,95^{\mathrm{c}}$ \\
$500 \mathrm{~g} / \mathrm{ph} /$ th NPK tablet (setara 50\% pupuk tunggal) & 39,94 & $39,81^{\mathrm{bc}}$ \\
250 g/ph/th NPK tablet (setara 25\% pupuk tunggal) & 40,04 & $40,65^{\mathrm{c}}$ \\
$150 \mathrm{~g} / \mathrm{ph} /$ th NPK tablet (setara 15\% pupuk tunggal) & 38,62 & $38,35^{\text {ab }}$ \\
\hline
\end{tabular}

Keterangan : angka yang diikuti huruf yang sama menunjukkan tidak berbeda nyata pada tingkat signifikasi $95 \%,{ }^{\text {tn }}$ : tidak nyata.

Sumber:Wijaya et al. (2014)

nyata antar perlakuan. Pada tahun kedua perlakuan pupuk majemuk NPK tablet setara $75 \%$ dosis umum pupuk tunggal merupakan perlakuan yang terbaik, namun tidak berbeda nyata dengan perlakuan pupuk majemuk NPK tablet setara 25\% dosis umum pupuk tunggal. Perlakuan pupuk majemuk NPK tablet setara $50 \%$ dosis umum tidak berbeda nyata dengan perlakuan dosis umum (Wijaya et al., 2014). Hasil penelitian tersebut dapat kita gunakan sebagai acuan untuk dosis penggunaan pupuk NPK tablet cukup 25\% dari dosis umum pupuk tunggal.

Berdasarkan hasil penelitian tersebut, apabila tidak dilakukan pemupukan pada tanaman menghasilkan selama satu tahun pertama belum memberikan dampak terhadap penurunan produksi. Namun pada tahun kedua setelah tidak dilakukan pemupukan dapat mengakibatkan penurunan produksi sebesar 4\% (Tabel 3). Hal ini dapat menjadi acuan bahwa pada saat kondisi harga karet rendah yang mengakibatkan pemilik kebun kesulitan dalam biaya pemupukan maka dapat dilakukan penundaan pemupukan sampai dua tahun. Secara ekonomi peningkatan produksi pada tahun kedua walaupun dengan pemupukan menggunakan pupuk majemuk NPK tablet setara $75 \%$ pupuk tunggal hanya $10 \%$. Artinya apabila diasumsikan produktivitas rata-rata kebun karet 1.500 $\mathrm{kg} / \mathrm{ha} /$ th dengan pemupukan, maka produksi akan menurun $10 \%$ menjadi $1.350 \mathrm{~kg} / \mathrm{ha} / \mathrm{th}$. Pada kondisi harga karet 1,5 USD/kg (1 USD 
$=$ Rp. 14.000), maka pekebun akan mengalami penurunan pendapatan sebesar Rp. 2.940.000,- (150 kg x 14.000). Penurunan pendapatan ini masih lebih rendah apabila dibandingkan dengan biaya pemupukan yang dikeluarkan, dengan asumsi rata-rata dosis pupuk majemuk untuk tanaman menghasilkan sebesar $750 \mathrm{gr} / \mathrm{p} / \mathrm{th}$, populasi $500 \mathrm{p} / \mathrm{ha}$, harga pupuk majemuk Rp. $8.000 / \mathrm{kg}$ dan biaya aplikasi Rp.270.000 (3 HK x @ Rp. 90.000), maka biaya pemupukan sebesar Rp. 3.270.000.

\section{Pupuk Hayati}

Pupuk hayati mempunyai peranan untuk meningkatkan efisiensi penggunaan pupuk anorganik, sehingga pencemaran lingkungan dapat dikurangi akibat pemakaian pupuk anorganik yang rendah. Penggunaan pupuk anorganik maupun organik sudah biasa dilakukan pada pertanaman karet, namun penggunaan pupuk hayati masih belum umum dilakukan. Pupuk hayati (biofertilizer) merupakan suatu inokulum mikroba yang mempunyai kemampuan untuk meningkatkan kelarutan hara dalam tanah yang dapat digunakan untuk semua jenis tanaman (wide spectrum). Pupuk hayati dalam penyajiannya dapat dikemas dalam suatu formula khusus berbentuk suspensi, bubuk, atau butiran. Mikroba (bakteri dan fungi) yang umum digunakan sebagai bahan aktif adalah bakteri penambat nitrogen, bakteri pelarut fosfat (BPF), dan mikoriza (Suhartatik \& Sismiyati 2000).

\section{1) Bakteri Penambat Nitrogen}

Sumber nitrogen $\left(\mathrm{N}_{2}\right)$ paling banyak terdapat di atmosfer, yaitu sekitar $78-80 \%$ dalam bentuk $\mathrm{N}_{2}$, nitrogen tidak dapat langsung dimanfaatkan oleh tanaman sehingga perlu diubah terlebih dahulu menjadi nitrat $\left(\mathrm{NO}_{3}\right)$ atau amonium $\left(\mathrm{NH}_{4}^{+}\right)$ agar dapat tersedia bagi tanaman (Handayanto \& Hairiah, 2007). Salah satu pendekatan untuk meningkatkan efisiensi penggunaan nitrogen yang tersedia dalam tanah adalah penggunaan mikroorganisme penambat nitrogen. Bakteri penambat nitrogen dikelompokkan menjadi dua yaitu kelompok bakteri penambat nitrogen yang bersimbiotik dan kelompok penambat nitrogen bebas non simbiotik. Penggunaan bakteri pemfiksasi nitrogen non simbiotik lebih luas dibandingkan dengan simbiotik. Genus bakteri pemfiksasi nitrogen non simbiotik aerob yang telah dikenal adalah Azospirillum, Derxia, Mycobacterium, Beijerinckia, Azomonas, dan Azotobacter (Widyastuti et al., 2010).

Penelitian yang dilakukan oleh Joseph et al. (1997) menunjukkan bahwa 50\% pupuk nitrogen dapat dikurangi penggunaannya melalui inokulasi Azotobacter sp. Hasil penelitian Joseph et al. (1997) yang disajikan pada Tabel 4 menunjukkan bahwa tinggi tanaman dan diameter batang pada empat perlakuan memiliki hasil yang berbeda. Tanaman yang diberi perlakuan 50\% dan $75 \%$ urea dengan inokulum Azotobactersp. memiliki

Tabel 4. Pengaruh dosis pupuk nitrogen dan inokulasi Azotobacter sp. terhadap pertumbuhan bibit batang bawah karet umur 12 bulan

\begin{tabular}{lcc}
\hline \multicolumn{1}{c}{ Perlakuan } & $\begin{array}{c}\text { Rata-rata tinggi } \\
\text { tanaman }(\mathrm{cm})\end{array}$ & $\begin{array}{c}\text { Rata-rata diameter } \\
\text { batang }(\mathrm{cm})\end{array}$ \\
\hline 25\% urea + inokulum Azotobacter sp. & $134,8^{\text {tn }}$ & $13,18^{\text {tn }}$ \\
$50 \%$ urea + inokulum Azotobacter sp. & 148,2 & 13,74 \\
$75 \%$ urea + inokulum Azotobacter sp. & 149,6 & 13,60 \\
$100 \%$ urea + tanpa inokulasi (kontrol) & 142,2 & 12,64 \\
\hline
\end{tabular}

Keterangan: ${ }^{\text {tn }}$; tidak nyata,

Sumber: Joseph et al. (1997) 
tinggi tanaman dan diameter batang yang lebih besar daripada perlakuan $25 \%$ urea dengan inokulum Azotobacter sp. dan kontrol (tanpa inokulasi Azotobactersp.).

Bakteri non simbiotik lainnya yang dapat dimanfaatkan adalah Azospirillum sp. Azospirillum sp. menambat nitrogen pada kondisi mikroaerofil. Nitrogen yang ditambat akan diserap oleh tanaman dalam bentuk $\mathrm{NO}_{3}$. dan $\mathrm{NH}_{4}^{+}$. Azospirillum sp. juga mampu menghasilkan zat pengatur tumbuh seperti Indole Acetic Acid (IAA), giberelin, auksin, dan senyawa yang menyerupai sitokinin (Rusmana \& Hadijaya, 1994).

Beberapa hasil penelitian menunjukkan bahwa pemanfaatan Azospirillim sp. dapat meningkatkan efisiensi pemupukan pada beberapa tanaman. Salah satu hasil penelitian mengenai pemanfaatan Azotobacter sp. dan Azospirillum sp. sebagai upaya untuk meningkatkan pertumbuhan tanaman karet dilaporkan oleh Hidayati (2005). Hasil penelitian menunjukkan rata-rata tinggi tanaman yang diperlakukan dengan inokulum Azospirillum sp. tanpa pemupukan urea memperlihatkan nilai tertinggi, sedangkan rata-rata diameter tanaman tertinggi terlihat pada perlakuan urea $50 \%+$ inokulum Azospirillum sp., pertumbuhan tanaman karet memiliki kecenderungan lebih baik dengan aplikasi inokulum jika dibandingkan dengan kontrol tanpa aplikasi inokulum (100\% urea), meskipun tidak berbeda nyata. Pemakaian urea dosis yang lebih rendah dari kontrol yaitu $50 \%$ ditambah dengan bakteri penambat $\mathrm{N}$ non simbiotik mampu meningkatkan pertumbuhan tanaman karet (Tabel 5). Hal ini diperkuat oleh Rusmana \& Hadijaya (1994) yang mengemukakan bahwa bakteri penambat $\mathrm{N}$ non simbiotik mampu menghasilkan zat pengatur tumbuh sehingga dapat meningkatkan efisiensi pemupukan $\mathrm{N}$.

Tabel 5. Pengaruh inokulum Azotobacter sp. dan Azospirillum sp. terhadap pertumbuhan bibit tanaman karet di polibeg umur empat bulan

\begin{tabular}{lcc}
\hline \multicolumn{1}{c}{ Perlakuan } & $\begin{array}{c}\text { Rata-rata tinggi } \\
\operatorname{tanaman}(\mathrm{cm})\end{array}$ & $\begin{array}{c}\text { Rata-rata diameter } \\
\text { batang }(\mathrm{cm})\end{array}$ \\
\hline Urea 100\% + tanpa inokulasi & $66,72^{\text {tn }}$ & $7,60{ }^{\text {tn }}$ \\
Tanpa dipupuk urea + inokulum Azotobacter sp. & 80,50 & 8,06 \\
Tanpa dipupuk urea + inokulum Azospirillum sp. & 81,71 & 8,20 \\
Urea 50\% + inokulum Azotobacter sp. & 78,03 & 8,09 \\
Urea 50\% + inokulum Azospirillum sp. & 78,40 & 8,67 \\
\hline
\end{tabular}

Keterangan: ${ }^{\text {tn }} ;$ tidak nyata

Sumber:Hidayati, (2005)

\section{2) Bakteri Pelarut Fosfat}

Upaya dalam meningkatkan ketersediaan $\mathrm{P}$ untuk tanaman melalui pemupukan telah banyak dilakukan, namun yang terserap hanya $10-30 \%$ dari pupuk $\mathrm{P}$ yang diaplikasikan. Hal ini terjadi karena adanya fiksasi $\mathrm{P}$ yang tinggi oleh tanah terhadap pupuk yang diberikan sehingga menjadi tidak tersedia terutama pada tanah mineral bereaksi masam. Pada tanah yang bereaksi masam, fosfor terfiksasi menjadi Fe-P dan Al-P dan mengakibatkan bentuk ini menjadi sulit diserap oleh tanaman (Buckman dan Brady, 1982).
Salah satu alternatif untuk mengatasi rendahnya P-tersedia tanah adalah dengan memanfaatkan mikrobia tanah yang hidup bebas dan memiliki kemampuan untuk melarutkan $\mathrm{P}$ pupuk maupun $\mathrm{P}$ tanah, seperti bakteri pelarut fosfat (BPF) (Hasanudin \& Gonggo, 2004). Kelompok BPF yang mempunyai kemampuan yang tinggi dalam melarutkan $\mathrm{P}$ yang terikat oleh unsur lain (Fe, $\mathrm{Al}$, Ca, dan $\mathrm{Mg}$ ) adalah Pseudomonas sp., Bacillus sp., B. megaterium, dan Chromobacterium sp. (Widawati, 2005). BPF berperan dalam transfer energi, penyusunan protein, koenzim, asam nukleat, vitamin, dan fitohormon yang 
dapat memperbaiki pertumbuhan akar tanaman serta meningkatkan serapan hara sehingga dapat meningkatkan efisiensi pemupukan(Glick, 1995; Rao, 1994).

Hasil penelitian pemanfaatan bakteri pelarut fosfat yang dilakukan oleh (Hidayati \& Wijaya, 2009) menunjukkan bahwa aplikasi menggunakan $\mathrm{BPF}+100 \%$ dosis pupuk SP36 memperlihatkan hara $\mathrm{P}$ tersedia tertinggi, sebesar 504,53 ppm (Tabel 6). Kandungan optimum $\mathrm{P}$ tersedia tanah untuk tanaman karet berkisar antara 16-25 ppm (Adiwiganda et al., 1994). Hal ini juga diperkuat oleh penelitian Goenadi et al. (1995) yang menginokulasikan mikroorganisme pelarut fosfat, Streptomyces sp. dan Aspergillus sp., pada Ultisol yang merupakan salah satu jenis tanah yang umum diusahakan sebagai lahan perkebunan. Aplikasi mikroorganisme tersebut mampu meningkatkan $\mathrm{P}$ tersedia dalam tanah dibandingkan tanpa inokulasi mikroorganisme.

Tabel 6. Hasil analisis $\mathrm{pH}$ dan unsur hara $\mathrm{P}$ tersedia ( $\mathrm{ppm}$ ) tanah pada beberapa perlakuan pemupukan di TBMkaret

\begin{tabular}{lccc}
\hline \multicolumn{1}{c}{ Perlakuan } & $\mathrm{pH}$ & P-tersedia $(\mathrm{ppm})$ & Kriteria P* $^{*}$ \\
\hline Kontrol (tanpa perlakuan) & 4,45 & 15,89 & Rendah \\
25\% SP36 & 4,24 & 9,19 & Rendah \\
$50 \%$ SP36 & 4,80 & 226,64 & Sangat tinggi \\
$100 \%$ SP36 & 4,71 & 450,59 & Sangat tinggi \\
Aplikasi BPF & 4,11 & 47,64 & Sangat tinggi \\
Aplikasi BPF + 25\% SP36 & 4,39 & 206,33 & Sangat tinggi \\
Aplikasi BPF + 50\% SP36 & 4,74 & 228,02 & Sangat tinggi \\
Aplikasi BPF + 100\% SP36 & 4,85 & 504,53 & Sangat tinggi \\
\hline
\end{tabular}

Sumber:Hidayati \& Wijaya, (2009)

*Berdasarkan kriteria hara tanah untuk tanaman karet yang dibuat olehAdiwiganda et al. (1994)

\section{3) Mikoriza}

Tanaman yang mengandung mikoriza dapat tumbuh lebih baik, karena mikoriza secara efektif dapat meningkatkan penyerapan unsur hara baik makro seperti P (Bolan, 1991), N dan K (Kabirun, 2002; Hasanudin, 2003) maupun mikro seperti $\mathrm{Cu}$ dan $\mathrm{Zn}$ (Tarafdar \& Rao, 1997). Selain itu, akar yang mengandung mikoriza dapat menyerap unsur hara dalam bentuk terikat dan yang tidak tersedia bagi tanaman (Anas, 1997). Menurut Kabirun (2004), Mikoriza Vesikula Arbuskular (MVA)/Jamur Mikoriza Arbuskular (JMA) mempunyai beberapa peranan yang penting bagi tanaman inang, seperti dapat meningkatkan resistensi terhadap kekeringan, meningkatkan penyerapan hara makro dan mikro, menekan penyakit akar, dan melindungi pengaruh toksik logam berat.

Saputra et al. (2014) melakukan penelitian pupuk hayati yang mengandung 200-250 spora mikoriza dalam setiap $10 \mathrm{~g}$ dan hasilnya disajikan pada Tabel 7. Perlakuan dengan hanya menggunakan pupuk hayati Mikoriza (100 gr/tanaman) meningkatkan pertumbuhan tanaman, namun pertumbuhannya masih di bawah pertumbuhan tanaman dengan pemupukan $100 \%$, $75 \%$, dan $50 \%$ dosis umum pupuk anorganik ditambah pupuk hayati 100 g/tanaman (perlakuan C, D, E dan F). Menurut Kabirun (2004), hal ini dikarenakan pupuk hayati tidak berfungsi sebagai penyedia 
Tabel 7. Pengaruh beberapa perlakuan terhadap lilit batang tanaman $(\mathrm{cm})$ pada umur tanaman 4,8 dan 12 bulan

\begin{tabular}{lllll}
\hline \multicolumn{1}{c}{ Perlakuan } & \multicolumn{4}{c}{ Lilit Batang (cm) } \\
\cline { 2 - 5 } & Awal & 4 Bulan & 8 Bulan & 12 Bulan \\
\hline A. Kontrol, tanpa pemupukan & $2,63 \mathrm{tn}$ & $4,29 \mathrm{tn}$ & $6,55 \mathrm{a}$ & $8,96 \mathrm{a}$ \\
$\begin{array}{l}\text { B. Pupuk hayati 100 g/tanaman } \\
\text { C. Dosis umum pupuk anorganik 100\% }\end{array}$ & 2,61 & 4,34 & $6,88 \mathrm{ab}$ & $9,17 \mathrm{a}$ \\
$\begin{array}{l}\text { D. } 100 \% \text { dosis umum + Pupuk hayati } \\
\quad 100 \mathrm{~g} / \text { tanaman }\end{array}$ & 2,38 & 4,18 & $7,59 \mathrm{c}$ & $10,82 \mathrm{~b}$ \\
$\begin{array}{l}\text { E. } 75 \% \text { dosis umum + Pupuk hayati } \\
\quad 100 \mathrm{~g} / \text { tanaman }\end{array}$ & 2,32 & 3,14 & $7,60 \mathrm{c}$ & $10,75 \mathrm{~b}$ \\
$\begin{array}{l}\text { F. } 50 \% \text { dosis umum + Pupuk hayati } \\
\quad 100 \mathrm{~g} / \text { tanaman }\end{array}$ & 2,58 & 4,20 & $7,19 \mathrm{abc}$ & $10,24 \mathrm{~b}$ \\
\hline
\end{tabular}

Keterangan : angka yang diikuti huruf yang sama menunjukkan tidak berbeda nyata pada tingkat signifikasi $95 \%$, tn: tidak nyata.

Sumber:Saputra et al. (2014)

hara bagi tanaman. Mikoriza berfungsi untuk meningkatkan kemampuan tanaman dalam penyerapan hara makro dan mikro dari tanah. Sehingga pemberian pupuk anorganik tidak dapat ditiadakan dan hanya dapat dikurangi dosisnya hingga $50 \%$.

Pertumbuhan tanaman dengan perlakuan $100 \%$, $75 \%$, dan $50 \%$ dosis umum pupuk anorganik ditambah pupuk hayati 100 $\mathrm{g} /$ tanaman memiliki pertumbuhan lilit batang yang secara statistik tidak berbeda nyata dengan tanaman yang dipupuk dengan 100\% pupuk anorganik. Hal ini mencerminkan bahwa pemberian pupuk hayati yang mengandung mikoriza dapat mengefisienkan penggunaan pupuk anorganik hingga $50 \%$. Selain itu pupuk anorganik ditambah pupuk hayati $100 \mathrm{~g} /$ tanaman (perlakuan C, D, E dan F) dapat meningkatkan pertumbuhan tanaman karet. Hasil ini sejalan dengan hasil penelitian Musfal (2010) menyatakan bahwa hasil jagung pipilan tidak berbeda nyata antara perlakuan pupuk NPK $100 \%$ dengan perlakuan NPK 50\% ditambah mikoriza 15 $\mathrm{g} /$ tanaman. Ikram et al. (1993) dan Istianto et al. (1995), menyebutkan bahwa inokulasi mikoriza pada pembibitan batang bawah tanaman karet dapat meningkatkan bobot kering dan diameter batang tanaman.

Kombinasi pupuk tunggal anorganik dengan pupuk hayati secara umum dapat menurunkan dosis pupuk tunggal anorganik $25-75 \%$. Apabila diasumsikan rata-rata total dosis pupuk tunggal untuk tanaman menghasilkan sebesar $1.000 \mathrm{gr} / \mathrm{p} / \mathrm{th}$, maka apabila menggunakan kombinasi dengan pupuk hayati $100 \mathrm{~g} /$ tanaman maka dosis pupuk majemuk yang digunakan hanya 500 $\mathrm{g} / \mathrm{p} / \mathrm{th}$ (50\% pupuk tunggal) dengan populasi 500 p/ha. Harga pupuk tunggal Rp. 6.000/kg dan harga pupuk hayati Rp. $20.000 / \mathrm{kg}$, jadi biaya pengadaan pupuk tunggal Rp. 1.500 .000 dan pupuk hayati Rp. 1.000.000. Biaya pengadaan pupuk tunggal $100 \%$ sebesar Rp. 3.000 .000 , artinya apabila menggunakan pupuk hayati telah menghemat biaya pembelian pupuk tunggal sebesar Rp. 500.000/ha. 


\section{Kesimpulan}

Strategi pemupukan yang dapat dilakukan pada perkebunan karet dalam rangka peningkatan efisiensi pemupukan antara lain penggunaan pupuk majemuk dengan tambahan slow release agent yang sering disebut dengan Slow Release Fertilizer (SRF) atau kombinasi pupuk tunggal dengan pupuk hayati. Penentuan dosis pemupukan harus mempertimbangkan kesuburan tanah dan kebutuhan hara tanaman. Hasil penelitian menunjukkan bahwa penggunaan pupuk majemuk NPK tablet dapat menggunakan dosis pupuk NPK tablet hanya $25 \%$ dari pupuk tunggal, sedangkan apabila menggunakan kombinasi pupuk tunggal dan hayati dapat menggunakan dosis $50 \%$ pupuk tunggal ditambah dengan 100 gram/pohon pupuk hayati. Penerapan beberapa alternatif teknologi tersebut dapat menggurangi dosis pemupukan hingga $75 \%$. Pada kondisi kesulitan melakukan pemupukan karena harga karet yang rendah maka penundaan pemupukan selama dua tahun belum memberikan efek kerugian finansial bagi pekebun. Produktivitas tanaman menurun namun penurunan produktivitas masih lebih menguntungkan bila dibandingkan dengan biaya pemupukan pada kondisi harga karet yang rendah.

\section{Daftar Pustaka}

Adiwiganda, Y. T., Hardjono, A., Manurung, A., Sihotang, U. T. B. D., Sudiharto, Goenadi, D. H., \& Sihombing, H. (1994). Teknik penyusunan rekomendasi pemupukan tanaman karet. Forum Komunikasi Karet, 1-17.

Anas, I. (1997). Bioteknologi Tanah. Bogor, Indonesia: Laboratorium Biologi Tanah. Jurusan Tanah. Fakultas Pertanian, IPB.

Bolan, N. S. (1991). A critical review on the role of mycorrizal fungi in the uptake of phosphorus by plants. Plant Soil, 134(2), 189-207.
Buckman, \& Brady, N. C. (1982). The nature and properties of soil (Terjemahan). Jakarta, Indonesia Bhratara Karya Aksara.

Glick, B. R. (1995). The enhancement of plant growth by free living bacteria. Canadian Journal Microbiology, 41, 109-117.

Goenadi, D. H., Saraswati, R., Nganro, N. N., \& Adiningsih, J. A. S. (1995). Mikroba pelarut hara dan pemantap agregat dari beberapa tanah tropika basah. Menara Perkebunan, 63(2), 60-66.

Handayanto, E., \& Hairiah, K. (2007). Biologi tanah: landasan pengelolaan tanah sehat. Yogyakarta, Indonesia: Pustaka Adipura.

Hasanudin. (2003). Peningkatan ketersediaan dan serapan $\mathrm{N}$ dan $\mathrm{P}$ serta hasil tanaman jagung melaui inokulasi mikoriza, azotobacter dan bahan organik pada Ultisol. Jurnal Ilmu Pertanian Indonesia, 5(2), 83-89.

Hasanudin, \& Gonggo, M. B. (2004). Pemanfaatan mikrobia pelarut fosfat dan mikoriza untuk perbaikan fosfor tersedia, serapan fosfor tanah (ultisol) dan hasil jagung (pada ultisol). Jurnal Ilmu-Ilmu Pertanian Indonesia, 6(1), 8-13.

Hidayati, U. (2005). Peranan mikroorganisme tanah dalam meningkatkan serapan nitrogen pada berbagai tingkatan ketersediaan air tanah. Jurnal Penelitian Karet, 23(2), 156-166.

Hidayati, U., \& Wijaya, T. (2009). Pemanfaatan bakteri pelarut fosfat untuk meningkatkan pertumbuhan tanaman karet. Jurnal Penelitian Karet, 27(1), 42-48.

Ikram, A., Mahmud, A. W., \& Othman, H. (1993). Growth response of hevea brasiliensis seedling rootstock to inoculation with vesicular-arbuscular mycorrhizal fungal species in steamsterilised soil. Journal of Natural Rubber Research, 8(3), 231-242.

Istianto. (2006). Daur hara di perkebunan karet dan pemupukan tanaman karet menggunakan pukalet. Warta Perkaretan, 25(1), 50-62. 
Istianto. (2010, 27-28 Juli). Teknologi pemupukan untuk meningkatkan efisiensi penggunaan pupuk di perkebunan karet. Tulisan disajikan pada Seminar Nasional Teknologi Pemupukan 2010, "Ansisipasi Menghadapi Kelangkaan dan Kenaikan Harga Pupuk", Palembang.

Istianto, Anas, I., Gunawan, A. W., \& Basuki. (1995). Pengaruh mikoriza VA dan batuan fosfat alam terhadap pertumbuhan dan serapan fosfor pada bibit karet (Hevea brasiliensis Muell. Arg.). Jurnal Penelitian Karet, 13(3), 239-250.

Joseph, K. T. G., Vimalakumari, Mathew, J., \& Kothandaraman, R. (1997). Effect of Azotobacter inoculation on rubber seedling. Indian Journal of Natural Rubber Research, 10(1), 34-38.

Kabirun, S. (2002). Tanggap padi gogo terhadap inokulasi mikoriza arburkula dan pemupukan fosfat di entisol. Jurnal Ilmu Tanah Dan Lingkungan, 3(2), 49-56.

Kabirun, S. (2004). Pidato Pengukuhan Jabatan Guru Besar dalam Ilmu Mikrobiologi: Peranan mikoriza arbuskula pada pertanian berkelanjutan. Yogyakarta, Indonesia: Fakultas Pertanian Universitas Gadjah Mada.

Musfal. (2010). Potensi cendawan mikoriza asbuskular untuk meningkatkan hasil tanaman jagung. . Jurnal Penelitian dan Pengembangan Pertanian, 29(4), 154-158.

Noeriwan, \& Noeriza. (2004). Teknik pelaksanaan pengaruh aplikasi pupuk nitrogen terhadap populasi tiga jenis gulma. Buletin Teknik Pertanian, 9(2), 91-97.

Rao, N. S. S. (1994). Mikroorganisme tanah dan pertumbuhan tanaman (2nd ed.). Jakarta, Indonesia: Universitas Indonesia.

Achmad, S. R., \& Susetyo, I. (2014). Pengaruh proses pencampuran dan cara aplikasi pupuk terhadap kehilangan unsur N. Warta Perkaretan, 33(1), 29-34.
Rusmana, I., \& Hadijaya, D. D. (1994). Aktivitas nitrogenase Azospirillum sp. dan efektivitas simbiotiknya dengan jagung. Jurnal Hayati, 1(2), 51-54.

Saputra, J., Ardika, R., \& Wijaya, T. (2014, 27 Oktober). Pengaruh pupuk hayati mikoriza terhadap efisiensi pupuk anorganik pada tanaman karet (Hevea Brasiliensis). Tulisan disajikan pada Seminar Nasional dalam Rangka Dies Natalis ke-51 Fakultas Pertanian UNSRI. Tema: Mewujudkan ketahanan pangan dalam menghadapi pasar bebas ASEAN, Palembang.

Sembiring, Y. R. V., Nugroho, P. A., \& Istianto. (2013). Kajian penggunaan mikroorganisme tanah untuk meningkatkan efisiensi pemupukan pada tanaman karet. Warta Perkaretan, 32(1), 7-15.

Sihotang, U. T. B., \& Istianto. (1994). Manajemen pemupukan tanaman karet. Forum Komunikasi Karet, 18-39.

Singapore/Malaysia Rubber Price. (2018). Singapore/malaysia rubber price historical data. Diakses dari https://ycharts.com/ indicators/singapore_malaysia_rubber_pri ce

Suhartatik, E., \& Sismiyati, R. (2000). Pemanfaatan pupuk organic dan agent hayati pada padi sawah. In Suwarno \& Kurnia (Eds.), Tonggak Kemajuan Teknologi Produksi Tanaman Pangan. Paket dan Komponen Teknologi Produksi Padi. Bogor, Indonesia: Pusat Penelitian dan Pengembangan Tanaman Pangan.

Tarafdar, J. C., \& Rao, A. V. (1997). Response of arid legumes to VAM fungal inoculation. Symbiosis, 22(3), 265-274.

Thomas, Budiman, A., \& Hidayati, U. (2003). Status hara kalium kaitannya dengan serangan penyakit daun Corrinespora pada klon RRIM 600. Warta Pusat Penelitian Karet, 22(1), 24-31. 
Widawati, S. S. (2005). Populasi bakteri pelarut fosfat (BPF) di Cikaniki, Gunung Botol, dan Ciptarasa, serta kemampuannya melarutkan P terikat di media Pikovskaya padat. Biodiversitas, 7(2), 109-113.

Widyastuti, H., Siswanto, \& Suharyanto. (2010). Karakterisasi dan seleksi beberapa isolat Azotobacter sp. untuk meningkatkan perkecambahan benih dan pertumbuhan tanaman. Buletin Plasma Nutfah, 16(2), 160167.
Wijaya, T., Ardika, R., \& Saputra, J. (2014). The effect of omission fertilizer application on rubber yield of PB 260. Current Agriculture Research Journal, 2(2), 68-72. 